УДК 65.014.1

https://doi.org/10.47533/2020.1606-146X.74

\author{
T. ZH. DEMESSINOV ${ }^{1}$, R. K. KONUSPAEV ${ }^{1}, Z H . Z^{*}$ ORALBAEVA ${ }^{2}$ \\ ${ }^{1}$ Sh. Ualikhanov Kokshetau State University, Kazakhstan \\ ${ }^{2}$ Al-Farabi Kazakh National University, Kazakhstan
}

\title{
PREREQUISITES FOR THE EMERGENCE AND IMPORTANCE OF STRATEGIC PLANNING IN THE ACTIVITIES OF MODERN ENTERPRISES
}

\begin{abstract}
This article discusses the emergence and importance of strategic planning in the activities of modern enterprises, the need for more effective procedures and strategic planning systems. Particular attention is paid to the dynamics of the spread and introduction of the strategic planning system in the practice of management of American companies in the 70s - early 80s. The constructive role of long-term planning in the further evolution of intrafirm strategic planning is seen in the fact that, as its shortcomings were revealed, the possible and necessary ways to eliminate them became clearer. It is possible to conclude that the processes of diversification had a very direct impact on the creation of conceptual approaches that formed the basis for strategic planning. Primarily, the segmentation of the entire range of business operations of the firm is dividing them according to certain pre-selected criteria into internally more or less homogeneous and, therefore, more manageable parts. A definite step in this direction has already been taken with a broad introduction into corporate practice of a divisional (or separate) organizational structure.
\end{abstract}

Keywords: planning, strategic planning, strategic management, long-term planning, diversification.

Until the late 1950s, the notion of "strategic planning" in the West fully coincided with the concept of long-term planning [1, p. 43]. It was assumed that the future can be predicted by extrapolation. Long-term goals were presented in the form of quantitative indicators of the increase in production. The emphasis in planning was placed on the assessment of the firm's needs for resources, the development and optimization of its budget. At the same time, possible changes in the external environment were not taken into account, and the strategic character of the plan turned into an operational one.

In our opinion, there is a noteworthy approach that was presented in the study of the identification of the need for strategic planning made by the supporters of the systems approach in the management of W. King and D. Cliland [2, p. 27-28]. The authors consider this need by identifying the relevant symptoms. In modern organizations there is an obvious need for more effective procedures and strategic planning systems. Such a need can manifest itself in various symptoms, which indicate that the organization does not fully realize its potential:

- the tendency of each manager to view the scope of his activity from the point of view of the discipline that is closer to him, regardless of whether this sphere requires a broader approach and full consideration

- «tunnel horizons»: managers are unable to recognize the diversity of the organization's goals, even when they have achieved a high position and can no longer afford the luxury of thinking in simplified categories related to the economical use of resources (namely, this type of thought is valued by the leaders of the lower rank)

- the bureaucracy of the organizational structure, adapted more to maintain the effectiveness and control of current operations than to stimulate innovations of a long-term nature

*Адрес для переписки. E-mail: oralbaeva_zhanar@mail.ru 
- the absence of an «organization» or procedure specifically designed to encourage the participation of managers in the creation of new products and services

- the opinion that planning is performed by the chief official or, on the contrary, by the staff of professional planners

- an incentive system, in which short-term results are evaluated above the efforts aimed at finding long-term opportunities

- the introduction of radically new planning systems in organizations without due regard for their influence on the motivation and behavior of managers who use them.

If these symptoms are present, the organization apparently did not properly prepare for the future. Such an organization only reacts to changes, but does not prepare them; planning in this organization cannot be considered effective, no matter how much resources are spent on it.

In a slightly different light, the conditions and prerequisites for the emergence of strategic planning, are considered by Y. Ushanov [3, p. 132]. In particular, the author does this through the prism of strengthening the instability of macroeconomic factors in the second half of the last century. The dynamics of the spread and introduction of the strategic planning system into the practice of management of American companies in the 1970s and early 1980s is inextricably linked to the unprecedented in its scale and multifaceted crises in the US economy by multiple rise in prices for energy and raw materials, the deepening of structural imbalances and differences in the conditions for the reproduction of individual industries, the weakening of the positions of American capital in the world capitalist economy, high inflation rates, stagnation in many branches of national economy, etc. Taken together, this led to a disorientation of investment processes in the country's economy and the formation of long-term trends in the decline in labor productivity. In particular, the growth in production over the years in the US economy was characterized by the following indicators: $1950-1960$ - 3.3\%, 1960-1970 - 3.8\%, 1970-1980 - 2.8\%, 1980-1985 - 2.5\%. Such a slowdown in economic growth, which began in the early 1970s was characteristic of six more developed countries of the world [4, pp. 183-197]. For the first time in the United States it has been openly acknowledged that much of the responsibility for the situation lies not only in the spontaneous play of market forces, but also on the economic strategies and policies, which for a long time carried out the main centers of economic power in the state-monopoly capitalism system. The crisis of this mechanism for regulating social reproduction that has triggered a revision of the strategy itself, the management mechanisms for its development and implementation at the level of both the government and individual monopolies.

I.V. Tulin, the prerequisites for the emergence of strategic planning, considers in a chronological order, analyzing the stages of development of intra-firm planning systems in capitalist corporations in the post-war period. The author built his analysis based on the most significant in-house innovations regarding the development of the systems of longrange planning. In this study, both progressive features and shortcomings of formalized planning systems were noted [5, pp. 1-10].

Long-term extrapolation planning could appear and firmly enter into the practice of intra-firm management only in conditions of a steadily growing economy. From this point of view, it differs radically from the strategic planning that has come to replace it, which was intended to become the main tool for long-term management in conditions where there 
are large differences between past and expected economic results, between past and future development trends. "Long-term planning," stresses a major American specialist in the field of internal management, A. Huxs, "can lead us to the misconception that we are creating a situation of sustained growth, whereas in reality we are going on the occasion of the most favorable external forces" [6, p. 13].

At the same time, it is obvious that long-term planning, which grew directly from the traditional systems of budget and financial planning and control, was at one time a methodologically progressive tool for managing the company's future development.

The wide application of long-term planning in industrial corporations allowed managers to gain some experience in developing long-range forecasts and plans, to get used to the very idea of the need for long-term planning, calculations of options for the future development of the organization and its environment.

The constructive role of long-term planning in the further evolution of intrafirm strategic planning is seen in the fact that as its shortcomings were revealed, the possible and necessary ways to eliminate them became clearer.

The most general objective basis of socialist planning is the level of development of the modern productive forces and the socialization of production. The developed system of the social division of labor and the cooperation of various types of production connected with it, a high concentration of production, rapid scientific and technological progress-all this creates an objective necessity of social regulation of production [7, p. 7].

From 1950 to 1970 there was an intensive increase in the level of product diversification of US corporations [8, p. 82].

The study of diversification programs from 1950 to 1986 in thirty-three large US companies highlighted interesting results. Entering a new field of activity in industry is carried out in $70 \%$ cases through the purchase of a controlling stake in other enterprises, about $10 \%$ - the creation of joint ventures and industries, and only $20 \%$ - through the independent organization of new enterprises. Moreover, for various reasons, newly established enterprises in $60 \%$ cases fall apart or their organizers are forced to abandon their independent business [9, pp. 126-160].

The failure of many diversification programs, in addition to purely economic reasons, is often associated with ignoring the most important requirements for implementing a competition strategy in conditions of diversification. First of all, due attention is paid to the fact that non-diversified enterprises compete, but only those entering into their composition of production. In addition, diversification inevitably increases costs and increases the complexity of management, which is a deterrent to the units created [10, pp. 121-122].

It is believed that by offering a whole range of goods and services, an enterprise can increase competitiveness and mitigate possible risks by eliminating rigid dependence on one single product or market.

The main advantage of diversification is the possibility of large enterprises receiving additional benefits from diversity.

The essence of this effect is that the production of many types of products within a single large enterprise is more profitable than the production of the same types of goods in smallspecialized enterprises. The main sources of the diversity effect are the following [11, p. 64]: 
- multi-purpose joint use of production facilities

- the concentration of the sales network (goods and services are sold through a single network, not necessarily joint)

- the possibility of transferring information, knowledge, technical and managerial experience from other industries

- multilateral training of employees and the variety of information they receive.

At the same time, diversification requires top management to focus on many areas of activity and weakens control over the situation in a particular market; this can lead to a weakening of the competitive position of the enterprise. The costs of entering a new industry can be quite large and reduce the size of the expected profit. Therefore, it is necessary to talk about the rational nature of diversification.

We should note that the processes of diversification had a very direct impact on the creation of conceptual approaches that formed the basis for strategic planning. First and foremost, the segmentation of the entire range of business operations of the firm, that is, dividing them according to certain pre-selected criteria into internally more or less homogeneous and, therefore, more manageable parts. A definite step in this direction has already been taken with a broad introduction into corporate practice of a divisional (or separate) organizational structure.

The well-known Hans Vissem management researcher, considering the prerequisites for the emergence of strategic planning, focuses on the qualitative aspects of this process. The author points out that «Qualitative aspects (Where do I invest money and How should I place human and financial resources?») replaced the detailed quantitative planning, which was typical for the stage of long-term planning. Strategic planning combines the methods of long-term planning with the techniques inherent in marketing planning [12, p. 177].

Strategic planning is an integral part of strategic management. It provides the implementation of the strategic plan, strategic control and identification of problematic situations. [13, p.29].

Strategic planning is a set of actions and decisions taken by management that lead to the development of specific strategies designed to help the organization achieve its goals $[14$, p. 282].

There are several interpretations of the concept of strategic planning. In particular, one of them is a long-term management concept, which «determines the long-term development goals and objectives of the company, the long-term course of action to achieve the goals and allocation of resources required to implement the strategy." [15, p. 12].

On the other hand, this concept is considered in the following sequence [16, p.141]:

- strategic analysis, consisting of analysis of the external environment and the internal environment and their combined assessment

- choice of strategic direction, including forecasting; the definition of mission and objectives, and the identification of strategic «discrepancies» between projections and objectives

- implementation of the strategy, which includes consideration of alternative strategies; analysis of each option on the competitiveness of options for the strategy, feasibility, risk, and so on; drawing up a strategy implementation plan. 
If we take into account that the term «conception» means something whole and complete about the subject of research, then, in our opinion, the most complete and detailed analysis is presented by V. Efremov [17, p. 6]. In particular, the author notes that «Numerous concepts of strategic planning, differing in some technological moments of designing solutions, remain similar in the main. All of them are in the power of the tectocentric paradigm; they are all subordinated to the idea of preserving a certain organizational entity - enterprise, firm, company, and corporation. With all evidence of the poor consistency of the terms and constraints of real business practices obtained within these concepts of conclusions, the tectocentric paradigm has never been called into question. At the same time, it has been theoretically proved and no one doubts that any organization is just a specific form of people's exercise of a certain joint activity.

\section{REFERENCES}

1 Dashevskaya G.M., Kleinikova V.G. Methods of strategic planning: International experience. - M., 1992. - p. 43.

2 King U., Cliland D. Strategic planning and economic policy. - M.: Progress, 1982. - 390 pp.

3 Management innovations in the United States. The problem of implementation / Ed. cand. of econ. Sciences Yu.A. Ushanov.- M.: Nauka, 1986. - 230 pp.

4 N.G. Macroeconomics. Translated from English. - Moscow: MSU Publishing House, 1994. pp. 183-197.

5 Strategic planning. «Management by objectives» / Ed. cand. of econ. sciences I.V. Tulin. - M., 1990. $-378 \mathrm{pp}$.

6 Hax A.C. and Mailuf N.S. Strategic Management and Integrative Perspective // Prentice-Hall, Inc., Englewood Cliffs. - N.-Y., 1984. - P. 13.

7 Planning of the National Economy of the USSR / Ed. L.Ya. Beri: textbook for econ. Faculties of universities. - Moscow: Economics, 1968. - 420 pp.

8 Scherer F., Ross D. Structure of the industrial markets / Translated from English.- M.: INFRA-M, 1997. - p. 82.

9 Porter M. Competition / trans. from English. - M: Williams, 2001. - pp. 126-160.

10 Azoev G.L. Competition: analysis, strategy and practice. - Moscow: Center for Economics and Marketing, 1996. - 256.

11 Rodionova VN, Fedorkova NV, Chekmenev AN Strategic management: Manual. - Moscow: Publishing house RIOR, 2003. - p. 64.

12 Vissema Kh. Management in business units (entrepreneurship and coordination in a decentralized company) / trans. from English. - M.: INFRA-M, 1996. - p. 177.

13 Strategic Planning: Textbook. Manual/ ed. A.N. Petrova. - 2nd ed. - SPb.: Znanie, GUEF, 2004. - $182 \mathrm{pp}$.

14 Meskon M., Albert M., Hedouri F. Fundamentals of Management. - M.: Delo, 1998. - p. 282.

15 Chandler Alfred D. Strategy and Structure. - Cambridge; Mass: MIT Press, 1962. - p. 12.

16 Owen A. How to implement the strategy. Reader «Change Management». - Moscow: LINK, 1996. - p. 141.

17 Efremov V.S. Organizations, business systems and strategic planning // Management in Russia and abroad. - 2001. - № 2. - p. 6. 


\title{
Т. Ж. ДЕМЕСИНОВ ${ }^{1}$, Р. К. КОНУСПАЕВ ${ }^{1}$, Ж. З. ОРАЛБАЕВА ${ }^{2}$
}

${ }^{1}$ Кокиетауский государственный университет им. Ш. Уалиханова, Казахстан

${ }^{2}$ Казахский национальный университет им. аль-Фараби, Казахстан

\section{ПРЕДПОСЫЛКИ ВОЗНИКНОВЕНИЯ И ЗНАЧЕНИЕ СТРАТЕГИЧЕСКОГО ПЛАНИРОВАНИЯ В ДЕЯТЕЛЬНОСТИ СОВРЕМЕННЫХ ПРЕДПРИЯТИЙ}

\begin{abstract}
В статье исследован вопрос о появлении и важности стратегического планирования в деятельности современных предприятий, необходимости более эффективных процедур и систем стратегического планирования. Особое внимание уделяется динамике распространения и внедрения системы стратегического планирования в практике управления американскими компаниями в 70-x - начале 80-х годов. Выделены и описаны характерные особенности долгосрочного планирования, особенности долгосрочного планирования экстраполяции. Конструктивная роль долгосрочного планирования в дальнейшей эволючии внутрифирменного стратегического планирования проявляется в том, что, по мере выявления его недостатков, возможные и необходимые способы их устранения стали более ясными. Можно сделать вывод о том, что процессы диверсификаиии оказали непосредственное влияние на создание концептуальных подходов, которые легли в основу стратегического планирования. Прежде всего, сегментирование всего спектра бизнес-операций фирмы делит их в соответствии с определенными заранее критериями на более или менее однородные и, следовательно, более управляемые части. Определенный шаг в этом направлении уже был сделан с широким внедрением в корпоративную практику организационной структуры.

Ключевые слова: планирование, стратегическое планирование, стратегическое управление, долгосрочное планирование, диверсификачия.
\end{abstract}

\section{Т. Ж. ДЕМЕСІНОВ ${ }^{1}$ Р. К. КОНУСПАЕВ ${ }^{1}$, Ж. З. ОРАЛБАЕВА}

${ }^{1}$ Ш. Уалиханов атындавы Көкиетау мемлекеттік университеті, Қазақстан ²л-Фараби атындавы Қазақ ұлттық университеті, Қазақстан

\section{КАЗІРГІ КӘСІПОРЫНДАРДЫН ҚЫЗМЕТІНДЕГІ СТРАТЕГИЯЛЫК ЖОСПАРЛАУДЫН ПАЙДА БОЛУЫНЫН АЛҒЫШАРТТАРЫ МЕН МАНЫЗЫ}

Бұл мақалада заманауи кәсіпорындардың стратегиялық жоспарлаудың пайда болуы мен маңыьздылыгы, тиімдірек рәсімдерге және стратегияльқ жоспарлау жүйелеріне қажеттілік қарастырылады. 70-жылдары және 80-ші жылдардың басында американдық компанияларды басқару тәжірибесінде стратегияльқ жоспарлау жүйесін енгізуге ерекше назар аударылды. Жұмыста ұзақ мерзімді жоспарлаудың өзіне тән ерекшеліктері аталады және ұзақ, мерзімді жоспарлау-экстраполяцияның ерекшеліктері сипатталады. Стратегияльқ жоспарлауды одан әрі дамытудавы ұзақ мерзімді жоспарлаудың сындарль рөлі және оның кемшіліктері анықталгандықтан, оларды жоюдың мүмкін және қажетті жолдары анықталды. Әртараптандыру проиестері стратегиялық жоспарлау үшін негіз құрайтын тұжырымдамалық тәсілдерді құрува тікелей әсер еткен деп қорытынды жасаува болады. Бірінші кезекте, фирманын іскерлік операчиялардың бүкіл ауқымын сегменттеу оларды алдын-ала тандалван белгілі бір критерийлерге сәйкес біртекті және көп басқарылатын бөліктерге бөледі. Бұл багытта белгілі бір қ̧адамдар ұйымдық құрылымды корпоративтік тәжірибеге кеңінен енгізу арқылы қуабылданды.

Түйін сөздер: жоспарлау, стратегиялық жоспарлау, стратегиялық басқару, Ұзақ мерзімді жоспарлау, әртараптандыру. 